\title{
Cortadora relative clauses: A comparative analysis between Spanish, Portuguese and French $^{1}$
}

\author{
Anahí Alba de la Fuente \\ Université de Montréal \\ anahi.alba.de.la.fuente@umontreal.ca \\ Enrique Pato \\ Université de Montréal \\ enrique.pato-maldonado@umontreal.ca
}

\section{Abstract}

This paper focuses on cortadora relative clauses - or non-pronominal relative clauses -, a special type of relativization registered in Rio de la Plata Spanish varieties in which the preposition is deleted or 'chopped' ('cortada'). This phenomenon is an example of preposition optionality and, within the framework of generative grammar, it has been previously studied in Portuguese (both Brazilian and European) and in French. The main goal of this paper is to show that this syntactic-discursive phenomenon is comparable in all these three closely related Romance languages, following the works of Kato and Nunes (2009), Kato (2010), Valer (2008), Kenedy (2002) and Tarallo (1983) for Portuguese, Bouchard (1981) for French, and Caviglia and Malcuori (2007) for Spanish. In cortadora

1 This work was supported by the Conseil de recherches en sciences humaines $d u$ Canada under Grant No. CRSH-410-2018-0526, by the Junta de Castilla y León + FEDER (SpainEurope) under Grant No. VA009P17, and by the Ministerio de Ciencia, Innovación y Universidades (Spain) under Grant No. PGC2018-097693-B-I00. We would like to thank the anonymous peer reviewers of Isogloss and the editors for their comments and suggestions. 
relative clauses, only inherent prepositions ( $a$, de, con, en, and por) can be deleted, and the relativized element occupies the topic position within a Topic Phrase. The data used for Spanish examples come from the Corpus oral de la lengua española en Montreal (COLEM).

Keywords: Cortadora Relative Clauses; Preposition Optionality; Spanish; Portuguese; French.

\section{Table of Contents}

\section{Introduction}

2. Cortadora relative clauses in Spanish

3. Cortadora relative clauses in other languages

4. Preposition optionality and other grammatical considerations

\section{Conclusions \\ References}

\section{Introduction}

In some varieties of Spanish, most notably in the Rio de la Plata region, a type of oblique relative clause in which the preposition is absent has been identified. Examples of these "cortadora" relative clauses are shown in (1a) (with an instrumental value) and (2a) (with an associative value) (cf. Di Tullio and Malcuori 2012: 417), and their Standard Spanish counterparts are shown in (1b) and ( $2 b)$ :

(1) a. Ayer me puse unos zapatos [que no podía caminar]. Yesterday REFL put.PAST some shoes [QUE NEG could walk] 'Yesterday I put on some shoes [that I could not walk].'

b. Ayer me puse unos zapatos [con los que no podía caminar].

Yesterday REFL put.PAST some shoes [with the QUE NEG could walk]

'Yesterday I put on some shoes [with which I could not walk].'

(2) a. Salí con unos amigos [que no se puede hablar de ciertos temas]. went.out with some friends [QUE NEG IMP can talk of certain subjects] 'I went out with some friends [who you cannot talk about certain subjects].'

b. Salí con unos amigos[con los que no se puede hablar de went.out with some friends [with the QUE NEG IMP can talk of ciertos temas]. certain subjects] 'I went out with some friends [with whom you cannot talk about certain subjects].' 
This construction is mainly present in spoken language, although it has also been documented in written language. In these clauses $(1 \mathrm{a}, 2 \mathrm{a})$, the preposition has been 'chopped' and que is the only formal syntactic link to the subordinating noun or DP. As Di Tullio and Malcuori (2012: 417) explain, this syntactic phenomenon can occur because the content of the antecedent, present in the main clause, is reproduced and replaced in the domain of the subordinate clause. In addition, the discursive context shared by the interlocutors further contributes to the recovery of the preposition:

(3) Y entonces los 'chiquilines' tuvieron que salir de la sala que estaban y... ir al patio. (COLEM, Uruguay, W-28).

'And then the kiddies had to leave the classroom that they were and... go to the schoolyard.'

While restricted to certain varieties of Spanish, this chopping phenomenon has also been identified in other Romance languages, such as French (Bouchard, 1981) and Portuguese (Kato, 2010; Valer, 2008; Tarallo, 1983). The presence of these non-standard structures in different languages raises various questions. For instance, if the preposition in a cortadora relative clause can be deleted, what kind of deletion is it and how can this phenomenon be accounted for in grammatical terms? When can the preposition be deleted, or, in other words, which types of prepositions can be optional? What do Spanish, Portuguese, and French have in common with regard to this particular phenomenon?

The aim of the present study is twofold: 1) to characterize the phenomenon of cortadora relative clauses found in Rio de la Plata (RdP) Spanish varieties, and 2) to compare these structures with 'chopping' relative clause phenomena found in Portuguese and in French. Thus, in order to address the above-mentioned questions, we first provide a description of cortadora relative clauses in RdP Spanish, a variety in which this syntactic construction is grammatical for speakers, in contrast with other varieties of Spanish. ${ }^{2}$ The data used in our analysis come primarily from the COLEM (Corpus oral de la lengua española en Montreal, Oral Corpus of the Spanish Language in Montreal), a corpus of spoken language from native immigrant speakers of different origins, including Argentina and Uruguay. Then, in section 3, we discuss the "chopping" phenomenon in French and in Portuguese, and present a number of different analyses that have been put forward to account for these structures in these two Romance languages. Finally, in section 4, we argue that Kato and Nunes (2009) and Kato's (2010) analysis of these structures in Brazilian Portuguese (BP) may also be applied to our data from RdP Spanish and discuss other grammatical considerations linked with this phenomenon, with special attention to the notion of preposition optionality.

2 Although not present in Standard Peninsular Spanish, this type of structure has been registered sporadically in rural areas of Spain. Some examples can be found in COSER (Corpus Oral y Sonoro del Español Rural): E: ¿Y cuál es la patrona del pueblo? I: ¿La patrona del pueblo que yo vivía? ('E: And what is the patron of the village? I: The patron of the village that I used to live?') (COSER3109-Lo Ferro, Murcia, W-74). 


\section{Cortadora relative clauses in Spanish}

\subsection{General remarks on cortadora relative clauses}

The question of what determines proper sentence formation in some varieties, but not in others, has been studied within various theoretical frameworks. With regard to the phenomenon examined in this paper, as seen in (4), non-pronominal relative clauses are preceded by que and the preposition that should otherwise appear has been 'chopped'. According to the Nueva gramática de la lengua española (RAE/ASALE, 2009: 3359), this 'chopping' strategy "corresponds to the speed, improvisation, and immediacy that characterize spoken language" (our translation). With the exception of Di Tullio and Malcuori (2012), this phenomenon has not been described in either descriptive or pedagogical grammars, and, when it has, it has often been treated as a mistake (cf., for example, Lope Blanch, 1986; Trujillo, 1990; Contro Castaldo, 2012, among others). However, as we will see in the following sections, no semantic information is lost in these structures, as the referent in the main clause, as well as other identification mechanisms (e.g. context or discourse information, gender/number concord and agreement, etc.), are still available for the speaker to recover any potential loss of information caused by the absence of the preposition:

(4) La época que ocurrió todo eso, yo tenía solo once años (COLEM, Argentina, W-49).

The epoch QUE occurred all that I had only eleven years

'The time when all this [the Argentinean dictatorship] happened, I was only 11 years old.'

This 'chopping' phenomenon can be explored in syntactic, semantic and pragmatic terms. From a pragmatic-discursive point of view, we can see, through the presence of these structures, that spontaneous communication can trigger various forms of relative clause organization. Cortadora clauses stand in contrast with standard forms and, given their marked status, their codification and processing is presumably different from standard relative clauses. From a syntactic point of view, relative clauses display an absence of the preposition that precedes the relativiser (the relative pronoun que).

a. Salió corriendo de la habitación que dormía porque la Left.3.SG running from the room QUE slept.3.SG because the alarma de incendios estaba sonando. (COLEM, Argentina, W-45). alarm of fires was sounding 'He left running from the room that he was sleeping because the fire alarm was ringing.'

b. La niñita lloraba por su perrito que había atropellado un coche (COLEM, Uruguay, W-23).

The little-girl cried.IMP for her puppy THAT had run-over a car 'The little girl was crying for her puppy, which had been run over by a car.' 
Thus, when it comes to providing a syntactic analysis for these structures, two main aspects must be addressed: the status of que and the syntactic process behind the absence of the preposition. With respect to the status of que, the boundaries between complementizers and relative pronouns are known to be rather blurry (e.g. Kayne, 1994). In the specific case of cortadora relative clauses, a key aspect of the analysis is whether que is still a relative pronoun (Kato, 2010) or whether it has lost its pronominal function, which also causes it to lose its syntactic role in the subordinate clause, and now acts as a complementizer (Tarallo, 1983).

As for the absence of the preposition, some authors defend that it is deleted during the derivation (cf. Kenedy, 2002), whereas other authors (cf. Kato, 2010) have argued that, in structures in which the preposition is missing, no preposition is actually selected in the numeration. $^{3}$

In order to be able to address these two aspects properly, it is necessary to determine the base structure for cortadora relative clauses. Not surprisingly, much of the debate revolves around this issue, and several diverging proposals have been put forward. We present Caviglia and Malcuori's (2007) account for RdP Spanish at the end of this section; Kenedy's (2002), Kato and Nunes (2009) and Kato's (2010) for Brazilian Portuguese in section 3.1; and Bouchard's (1981) for French in section 3.2.

\subsection{Cortadora relatives in RdP Spanish}

The elision of a preposition in relative clauses is not possible in Standard Spanish, with only very marginal exceptions registered in informal speech, where we can find utterances like the one in $(6):^{4}$

El hombre (al) que mataron.

'The man who they killed.'

In contrast, as we have seen in examples (4) and (5a) above, RdP varieties allow for preposition dropping in a wider number of contexts. However, this 'chopping' strategy is not possible with all prepositions. Specifically, both cortadora and standard relative clauses are possible with prepositions such as $a$, de, con, en, and por. In contrast, two syllable prepositions, such as bajo, contra, entre, sobre, which are prepositions with a

3 A similar argument can be found in Trujillo (1990: 24), who notes that, in cases like the pair displayed in (i) and (ii), the difference is a syntactic one. Specifically, the sentence in (i) is an adjectival clause, whereas the one in (ii) would be a clause with a consecutive value:

i. Este es un libro con el que te partes de risa.

This is a book with the QUE REFL split of laughter

'This is a book with which you burst out laughing.'

ii. Este es un libro que te partes de risa.

This is a book QUE REFL split of laughter

'This is a book that you burst out laughing.'

4 In this case, the dropped element is the $a$ in the DO which, in the generative literature is assumed not to be a preposition, but rather a Differential object marker (DOM). Under this analysis, (7a) would not strictly be considered to be an example of preposition dropping. 
higher lexical content (cf. RAE/ASALE, 2009: 3302), cannot be deleted and, therefore, only the standard relative clause is possible in these cases (El equipo *(contra el) que jugamos 'The team against which we play'). Examples in (7a-c), with prepositions $a$, en, and con, are registered in RdP Spanish varieties, where there is a close semantic relation between the prepositional phrase (PP) and its licensing verb:

a. La escuela (a la) que íbamos [Verb: ir a].

'The school we used to go to.'

b. La casa (en la) que vivíamos [Verb: vivir en].

'The house we used to live in.'

c. El amigo (con el) que jugábamos [Verb: jugar con].

'The friend we used to play with.'

So, even though the phenomenon of preposition deletion is also present in Standard Spanish, as shown in (6 and 7), it is a very marginal phenomenon, and the contexts in which it occurs and the frequency with which it appears are much more restricted than in the RdP varieties.

As well, in Standard Spanish, non-pronominal relative clauses are subject to island constraints, as shown in (8). Specifically, argumental complements can be relativized, as illustrated in (8a), but adjuncts cannot, as in (8b). In (8a), the noun foto, like other representational nouns, has an internal argument that corresponds to the object represented (cf. Bosque and Gutiérrez-Rexach, 2009: 269).

a. El chico del que vi una foto.

'The boy of whom I saw a photo.'

b. *El chico del que vi un reloj.

'*The boy of whom I saw a watch.'

Taking into account previous work on RdP Spanish (cf. Caviglia and Malcuori, 2007), and the data from our corpus (COLEM), the contexts in which cortadora relative clauses may appear would be the following:

(9) a. Indefinite NPs with a specific interpretation: Me hicieron unos lentes que no veo ('They made me some glasses that I do not see (with them).'); No lo soporto, es una persona que le gusta decir tonterías ('I can't stand him, he's a person who likes saying dumb things.').

b. NPs + Demonstrative: Está ahora en el barrio ese que yo vivía antes ('He is now in that neighbourhood I used to live (in) before.'); El lugar ese que vive su familia está cerca de Córdoba, en Argentina, sí ('The place that his family lives (in) is close to Córdoba, in Argentina, yes.').

c. Demonstrative + ser + NP: Ese es el traje que yo me casé ('That is the suit that I married (in).'); [Metro] Este es el supermercado que yo compro ('[Metro] This is the supermarket that I buy groceries (in).'); Esa es la pastelería que compro las masas ('That is the bakery that I buy masas (in).').

d. NPs with a definite article with restrictive value: La chica que yo bailé ('The girl 
that I danced (with).'); [Claudia y Gabriela] Son las chicas que salgo los fines de semana ("[Claudia and Gabriela] they are the girls that I go out on the weekends (with).').

e. Non-restrictive relatives: No está en la casa... se fue de viaje con su mujer, que han operado de cáncer ('He is not at home... he went traveling with his wife, (to) whom they operated for cancer.').

As the previous examples indicate, the antecedents in the attested cases of cortadora relatives in RdP Spanish have [+specific] and [ \pm animate] features, and their most frequent syntactic functions are those of an $\mathrm{IO}(a(l)$ que/que), a nominal complement $(d e(l)$ que/que), and an adverbial adjunct (en que/que, con que/que).

In their syntactic analysis of these structures, which is based on Kato (1993), Caviglia and Malcuori (2007) argue that the relative position of cortadora clauses would be the topic (TOP) in topic-commentary structures. In other words, while in Standard Spanish (cf. 10a) the relativized element is in a position that is internal to the clause, in RdP Spanish varieties (cf. 10b), it is the phrase in topic position that is relativized:

a. El amigo [con el que $_{i}$ [yo juego al tenis oPi]]. The friend with the QUE I play to-the tennis 'The friend with whom I play tennis.'

b. El amigo [que $_{i}$ [торі [yo juego al tenis øi]]]. The friend QUE I play to-the tennis

'The friend who I play tennis.'

Caviglia and Malcuori (2007: 67) further argue that the base structure for (10b) $E l$ amigo que yo juego al tenis ('The friend who I play tennis.') is not Yo juego al tenis con este amigo ('I play tennis with this friend.') but rather Este amigo, yo juego al tenis ('This friend, I play tennis.') (Topic-Comment). As such, any element occupying the topic position in this type of structure may be subject to relativization. An equivalent example to the one provided by Caviglia and Malcuori (2007) is documented in our corpus ([тор Joel $l_{\mathrm{i}}$ [o yo practico curling øi]] 'Joel, I curl.'):

(11) $[¿ Y \ldots$ es tu pareja?] ¡Noo! Joel es el chico quebeco que [And... is your partner? Noo! Joel is the boy Quebecker that practico curling, solo amigos. (COLEM, Argentina, M-38). practice.1.SG curling only friends

'[And... is he your partner?] No way! Joel is the Quebecker guy I play curling with, just friends.'

In the following sections, we discuss alternative analyses for the cortadora phenomenon in Portuguese and French. In section 4, we further compare these two languages with RdP Spanish and argue that one of the alternative analyses, namely the one proposed by Kato (2010), seems to better accommodate the data in all three languages. 


\section{Cortadora relative clauses in other languages}

In this section, we first present a summary of the most relevant work on cortadora relative clauses in Portuguese and in French and, then, proceed to establish some links with this phenomenon in RdP Spanish. With respect to Portuguese, we focus on the proposals by Tarallo (1983), Kenedy (2002), Kato and Nunes (2009) and Kato (2010). In the case of French, we concentrate on the analysis proposed by Bouchard (1981).

\subsection{Cortadora Relative Clauses in Portuguese}

As Tarallo (1983) explains, there are three types of relative clauses in BP: 1) standard, 2) resumptive, and 3) chopping relatives or cortadoras. Whereas standard relatives display mandatory pied-piping in the presence of PPs (12a), resumptive relatives include a merged pronominal complement, which includes the preposition and a co-referent DP that merges at LD (12b). Finally, we have cortadora relatives (12c), where the preposition is absent and the relativized DP appears dislocated to the left periphery.
a. $\mathrm{O}$ autor *(com) quem falei. the author with who talked-1.SG
b. $\mathrm{O}$ autor que eu falei com ele the author who I talked prep with
c. $\mathrm{O}$ autor que eu falei
the author who I talked
'The author that I talked with.'

Documented since the end of the $19^{\text {th }}$ century in BP (cf. Tarallo 1983: 371) and also attested in European Portuguese, ${ }^{5}$ the cortadora clauses have been argued to be formed by a process of ellipsis of the duplicating element in the depronominalised relative (cf. among others, Tarallo, 1983; Barros, 2000; Neves, 2000; Bagno, 2001; Burgos, 2003; Kato and Nunes, 2009; Bispo, 2009; Castilho, 2010; Kato, 2010; Moura et al., 2010). ${ }^{6}$ As we will see below, according to Kato and Nunes (2009) and Kato (2010), the prepositions that can be 'chopped' are the ones that are inherent case assigners. This includes prepositions in PPs that are subcategorized by the verb (e.g. 'cut with a knife'), but also prepositions in PPs that are genitive complements and those in PPs that are indirect objects (cf. Kato, 2010: 177, and also Moura et al., 2010: 132-134).

Following Tarallo (1983), Valer (2008: 93) explains that the two non-standard relative clauses - namely resumptive and cortadora - are in complementary distribution.

$5 \quad$ Mateus and Cardeira (2007: 70-71) state that $28 \%$ of the recorded instances of relative clauses involve "chopped" relatives. As these authors explain, "this syntactic change brings both Portuguese varieties (European and Brazilian) closer together on a matter that has been presented in traditional grammars as one of the most notorious differences between them" (our translation).

6 According to Neves (2000: 381), it is often the case that "a preposition is deleted before the relative indirect object pronoun, especially the preposition $d e$, and especially with the verb gostar" (our translation). 
Specifically, resumptive pronouns tend to occur with DPs that are [+human] and [+definite], whereas cortadoras appear more frequently with [-human] and [-definite] DPs. ${ }^{7}$ The chopping strategy also tends to occur when the relative clauses are very separate from their antecedent and they are registered mostly in uneducated speakers and in informal speech (cf. Tarallo 1983). ${ }^{8}$

In addition, the relativized component is always a DP, and, as discussed above, the chopped relative clauses are only possible with prepositions that are inherent case assigners, such as prepositions in PPs that are subcategorized by the verb. This is the case of com ('with') in sentences like the one presented in (13):

*Vamos fazer a viagem [[que] [tu sonhas com $\left.\left.[e c]_{\mathrm{i}}\right]\right]$.

'We are going to do the trip that you dream of.'

By contrast, in cases that include prepositions such as sobre (14a), sem (14b) or contra (14c), the preposition must remain present. In fact, these clauses are ungrammatical, or dispreferred, if the preposition is absent (cf. Valer 2008: 39). ${ }^{9}$

a. Você deve esquecer o assunto $\left[[q u e]_{i}\right.$ eu te falei sobre $\left.[e c]_{i}\right]$.

'You should forget the subject that I spoke to you about.'

b. Ele perdeu o livro [[que $]_{i}$ ele não vive sem $\left.[e c]_{i}\right]$.

'He lost the book that he cannot live without.'

c. O casamento $\left[[q u e]_{i}\right.$ ele foi contra $\left.[e c]_{i}\right]$ acabou dando certo.

'The marriage that he was against ended up doing well.'

According to Bispo (2009: 98), prepositions that can be 'chopped' in BP include a/com $(100 \%)$, de $(90.4 \%)$, por $(81.8 \%)$, and em $(77.4 \%)$. Incidentally, these are the same prepositions found to be 'chopped' in RdP Spanish ( $a$, de, con, en, and por). ${ }^{10}$ In sum, non-

7 Even though there is a preference for [-human] DPs, we do find examples of cortadora relative clauses with [+human] DPs, as illustrated in examples such as (13c) and (14b), below.

$8 \quad$ Gomes Silva and dos Santos Lopes (2007: 88) show that cortadora relative clauses in the city of Rio de Janeiro are more abundant in the spoken language (31\%), although they are also recorded in the written language $(21 \%)$. Their use decreases in the written language as the informants' level of schooling increases. This is not the case in the spoken language, which is more consistent across the board.

9 As we can see in example 11, the resulting structures are instances of preposition stranding. This constitutes a notable difference with Spanish, in which preposition stranding is ungrammatical even in varieties in which the cortadora structure has been registered. This difference between Spanish and Portuguese will be further discussed in section 4.

10 With regard to European Portuguese, Arim, Ramilo and Freitas (2005: 70) show that with verbs such as precisar (de), the preposition is deleted in almost $100 \%$ of the examples, with gostar (de) in 83\%, chamar (a) 83\%, and falar (de) 74\%. Regardless of the value that we place on the percentage, the fact is that the data show that certain verbs are more inclined to recover the preposition than others. Varejão (2006: 131) shows that cortadora relative clauses are at $70 \%$ in rural Portuguese (data from the Corpus Dialectal para o Estudo da 
inherent or 'real' prepositions are mandatory and inherent ones are optional (cf. Kato, 2010: 178).

Depending on the type of verb, we find verbs that do not select a PP complement (cf. 15a, a locative adjunct), others that select one PP complement (cf. 15b), and a third kind that selects two or more PP complements (cf. 15c) (cf. Tarallo, 1983; Valer, 2008: 94):

a. Nova York é uma cidade [que [em que] você respira Gershwin]. 'New York is a city that [in which] you breathe Gershwin.'

b. Eu não ligo para piscina. É uma coisa [que [para que/a qual] eu não ligo ec]. 'I don't care for pools. It is a thing that [for which] I don't care.'

c. Mas ele saiu de casa faz uns seis meses; está morando com um outro rapaz [que [com que/quem/o qual/; *para/*em] ele trabalha $e c$ ].

'But he left home about six months ago; he is living with another boy that [with whom/which] he works.'

Regarding verbs without a PP complement, chopping the preposition does not cause ambiguity (cf. 15a), as it can be recovered from the lexicon. The verb in example (15b) does not cause ambiguity either. In (15c), however, the chop may cause ambiguity, but the [+human] feature of the head of the DP (rapaz) helps eliminate it. ${ }^{11}$

Regarding syntactic factors (cf. Tarallo, 1983), the most common syntactic function for chopped relatives is that of IO (the same syntactic function that was presented for Spanish data in $\S 2$ ) (cf. Moura et al., 2010: 133):

(16) a. (Para) o moto-boy, eu entreguei os documentos esta manhã. '(To) the motorcycle courier, I gave the documents this morning.'

b. Eu não encontro o moto-boy que eu entreguei os documentos essa manhã. 'I can't find the motorcycle courier that I gave the documents this morning.'

The 'chop' can also occur in other positions, such as Discourse-linked (D-linked) questions like the one illustrated in (17a), but it is not allowed in non D-linked questions such as (17b) (cf. Kato, 2010: 179):

a. (Com) que faca (é) (que) você cortou o queijo?

'Which knife did you cut the cheese with?'

b. *(Com) o que (que) você cortou o queijo?

'What did you cut the cheese with?'

Sintaxe). The cortadora relative reaches $90 \%$ in the spoken language's PP (Arim, Ramilo and Freitas 2005: 124).

11 Among verbs with two or more complements, the verb falar ('to speak') is one of the most ambiguous in terms of the thematic role of its complements (a, com, de, para, sobre). The verbs bater ('to beat'), berrar ('to bellow'), contar ('to tell'), chegar ('to arrive'), descer ('to go down'), perguntar ('to ask'), vir ('to come'), viver ('to live'), morar ('to reside'), trabalhar ('to work'), by contrast, have been argued to me much more straightforward in terms of semantic processing (cf. Tarallo, 1983; Valer, 2008: 94). 
The 'chop' is also possible in topic constructions, as shown in (18b) (cf. Kato, 2010: 175), and in cleft sentences or emphatic clauses (cf. Kato, 2010: 176, 180), as in (19).

a. (Com) aquela moça eu conversei ontem na festa. 'That girl, I talked with her yesterday at the party.'

b. A moça (com) que(m) eu conversei na festa.

'The girl that I talked with at the party.'

(19) Foi (com) essa professora que eu conversei ontem.

'It was with this teacher that I talked yesterday.'

In terms of the syntactic analysis, and returning to the issue, mentioned in section 2 , of determining the base structure for these relative clauses, we find two alternative analyses for cortadora relatives in Portuguese. To illustrate each analysis, we first present Kenedy's (2002) proposal and, then, proceed to discuss the work by Kato and Nunes (2009) and Kato (2010). ${ }^{12}$

Building on Salles (1997), Kenedy (2002: 143) presents an analysis of cortadora relative clauses that involves two movements: 1) copying the relative DP [que moça] in the SpecCP; subsequently copying the NP [moça], $D_{\text {rel }}$ complement in SpecDP, and 2) chopping the copy of the DP that occupies the lowest position of the chain, and chopping the preposition in situ, as certain constituent features of the DP are also apparent in the PP. The derivation proposed in this analysis is presented in (20).

a. A moça que eu falei.

'The girl that I spoke with'.

b. [DP a [CP moça]k [D que [NP meçak] [IP eu falei [PP eөm [DP que meça] ] ]]]].

[DP a [CP [DP [NP moça $]_{k}[\mathrm{D}$ que [NP møȩâ $\left.\left.\left.]_{i}\right]\right]\right]$.

Under this analysis, the preposition in cortadora relative clauses is deleted during the derivation, thus resulting in a sentence that has a left periphery constituent and an empty category $(e c)$ in the relativized position.

(21) Vamos fazer a viagem [[que] [tu sonhas eem $\left.\left.[e c]_{\mathrm{i}}\right]\right]$.

'We are going to do the trip that you dream (of).'

In contrast with Kenedy (2002) - and Tarallo (1983) -, Kato and Nunes (2009) propose to analyze BP relatives not as that-relatives but as wh-relatives, where que is a relative, rather than a complementizer. The authors explain that this approach crucially allows for a unique derivation for relatives in BP and is more successful in accommodating

12 Note that Valer (2008) refers to Kenedy's (2002) study as Areas (2002). 
a number of asymmetries found in Romance (p. 83). ${ }^{13}$ Under this analysis, which builds on Kato (1993), "the difference between the three types of relative clauses is not in terms of the grammatical resources employed, but rather the launching site of the movement of the relative pronoun que" (Kato and Nunes, 2009: 91). Thus, standard relatives are the result of que being generated in an argument position, after moving to SpecCP and with the corresponding pied-piping and island effects in the presence of PPs. In turn, non-standard relatives occur when que is generated in the left dislocation position. In the case of resumptives, the preposition is merged with the pronominal element, and a co-referent DP merges in the left periphery. In the case of cortadora relatives, no preposition is actually selected in the numeration, so the "orphan" DP complement has to move to TopP (Topical Phrase), so that it can be assigned nominative case by default. The derivation of these structures in BP, French and RdP Spanish, following Kato (2010: 181), is illustrated in (2224).

a. O autor que eu falei.

'The autor that I talked with.'

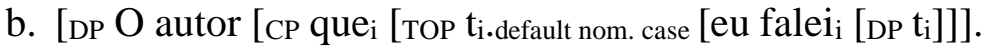

a. Le couteau que je coupe.

'The knife that I cut (with).'

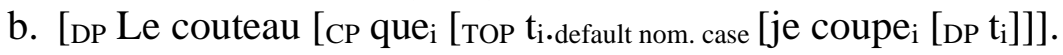

a. La chica que yo bailé.

'The girl who I danced (with).'

b. [DP La chica [CP que [TOP $_{\mathrm{i} \cdot \text { default nom. case }}$ [yo bailé $\left.\left.{ }_{i}\left[\mathrm{DP} \mathrm{t}_{\mathrm{i}}\right]\right]\right]$.

In order to account for the optionality of the preposition in relative clauses, Kato (2010) argues that some prepositions, namely 'inherent' case marking prepositions (ICP), "can be optional in the numeration" (p. 183). In these cases, the preposition can be deleted because it is in close semantic relation to the verb (falar com, couper avec, hablar con).

\subsection{Cortadora Relative Clauses in French}

With respect to French, Bouchard (1981) first showed the contexts in which the preposition can be absent. The point of departure is that only strictly subcategorized elements may undergo preposition 'chopping', as their recoverability is, at least partially, warranted by the context. In seemingly contradictory examples, such as (25a), Bouchard argues that the verb couper ('to cut') strictly subcategorizes an instrumental PP, in contrast with examples such as (25b), where this relationship does not exist between the verb manger ('to eat') and the NP (cuillère 'spoon'). In other words, the PP in (25a) has a close semantic connection with the verb and contains semantic content that makes the preposition recoverable if

13 Some of these asymmetries involve quem, which can function as a subject if it is a relative pronoun, as in Quem viu o professor? 'Who saw the professor', but not if it is a relative pronoun, as in *A pessoa quem vui o professor 'The person who saw the professor'. For further details, see Kato and Nunes (2009: 80-82). 
deleted (cf. Bouchard, 1981: 219):

a. Le couteau que je coupe (n'est pas coupant). ${ }^{14}$

'The knife that I cut (with) (is not sharp).'

b. *La cuillère que je mange est trop grosse.

'*The spoon that I eat is too big.'

c. La cuillère que je mange avec est trop grosse. ${ }^{15}$

'The spoon that I eat with is too big.'

In this case, the preposition avec ('with') is instrumental and the verb couper subcategorizes for [+instrumental] complements. By contrast, examples such as (26a) seem ambiguous (cf. Bouchard, 1981: 220):

a. Le fil que je coupe.

'The wire that I cut.'

a1. Le fil que je coupe (DO).

'The wire that I cut.'

a2. Le fil que je coupe avec (PP instrument).

'The wire that I cut with.'

b. Le fil que je coupe le fromage.

'The wire that I cut the cheese.'

Therefore, as we saw in Portuguese, in French the preposition can be erased from a PP only if it is semantically related to the verb, or "thematic", following Kato (2010: 173). In other words, the preposition can be deleted when it is strictly subcategorized, as it can be recovered in the lexicon. As well, in Quebec French (cf. Vinet, 1979: 117), the preposition may also be deleted when it is part of a verbal complex, namely, when the preposition is implicit in the semantic content of the verb:

(27) La maison que je viens là.

'The house that I come there.'

(28) a. Elle ramasse des fleurs avec les enfants. 'She collects flowers with the children.'

b. *Les enfants qu'elle ramasse des fleurs.

'The children who she collects flowers.'

These examples come from Remacle (1960): Je coupe le fromage avec le couteau ('I cut the cheese with the knife'), Je coupe le fromage ('I cut the cheese'), Le couteau que je coupe ('The knife that I cut').

15 Languages such as English and French, in examples such as (25c), allow for preposition stranding. This option, however, is not available in Spanish and, as such, the equivalent of (25c), * La cuchara que como con es demasiado grande, would be ungrammatical even in varieties in which cortadora relative clauses are possible. 
Bouchard (1981: 220), who works under the assumption that que is a complementizer (cf. Kato, 2010: 183), further argues that these constructions are base generated and that, in French, the preposition cannot be deleted when there is movement, which triggers mandatory pied-piping, such as in interrogative sentences (29). ${ }^{16}$

a. *Qu'est-ce que tu coupes le fromage (avec)?

'What do you cut the cheese (with)?'

b. Avec quoi est-ce que tu coupes le fromage?

'What do you cut the cheese with?'

This restriction is accounted for in Kato's (2010) analysis, who explains that, if the preposition is selected in the numeration, "deletion can never occur, either during the derivation or post-syntactically, at PF" (p. 183). In addition, Kato also agrees with Bouchard on the fact that preposition optionality is not favoured with PPs that are not subcategorized by the verb. As we have seen in section 3.1, Kato (2010) assumes that the que of these relative clauses would not be a complementizer, in contrast with Bouchard (1981) for French, or Tarallo (1983) for BP, but rather a nominative relative pronoun, following Kato (2010: 182).

\subsection{Interim summary}

In this section, we have seen that, in cortadora relative clauses, the relativized DP and the preposition are both absent from the relative clause. In terms of the syntactic analysis, we have seen two divergent analysis for que. According to one analysis, que behaves like a complementizer (e.g. Bouchard, 1981 for French; Tarallo, 1983 and Kenedy, 2002 for BP), whereas other authors analyze que as a relative determiner (e.g. Kato and Nunes, 2009 and Kato, 2010). In terms of the absence of the preposition, authors such as Kenedy (2002) argue that it is deleted during the derivation, whereas Kato (2010) defends that no preposition is actually selected in the numeration. All accounts share the notion that the 'chopping' - or non-selection - of the preposition is possible in cases in which the preposition has a close semantic relation with the verb that licenses it.

In terms of the syntactic derivation, the preposition optionality analysis presents us with two possibilities. In the first case, the preposition is selected in the numeration and the derivation proceeds normally, resulting in a standard relative structure with pied-piping. Alternatively, if no preposition is selected in the numeration, the "orphan" DP merged in complement position has to move to the left periphery in order to receive default nominative case. Under this analysis, the preposition may or may not be selected in the numeration, but, if it is selected, it cannot be deleted at any point in the derivation of postsyntactically (Kato, 2010: 183). One particularly appealing factor of Kato and Nunes (2009) and Kato's (2010) analysis is that it is able to provide a uniform analysis for all three types of relatives that exist in BP.

16 As discussed in section 4 of this paper, see Kato (2010) for BP, chopping is possible in these contexts. 
In the following section, we discuss Kato's argument on preposition optionality in further detail, and explore grammatical considerations on preposition stranding as it relates to relative clauses and the cortadora phenomenon.

\section{Preposition optionality and other grammatical considerations}

In this section, we continue our analysis of RdP Spanish, BP and Quebec French, and provide further details on which prepositions show optionality in each language. We further compare the three languages by exploring the issue of preposition stranding and conclude by suggesting a common account for relative clauses and cortadora phenomena in all three languages.

\subsection{Preposition optionality}

As we saw in section 3.1, prepositions that can be 'chopped' in BP include a, com, de, em, and por. These are the same prepositions found to be 'chopped' in RdP Spanish ( $a$, con, de, en, and por). ${ }^{17}$ With respect to French, based on Bouchard's examples, we also see deletion of these same prepositions. Specifically, the examples in section 3.2 illustrate the deletion of prepositions avec and de. In these cases, the preposition can be deleted because it is in close semantic relation to the verb (falar com, couper avec, hablar con), and, across the three languages, we find that only some prepositions show this optionality. Thus, we would like to argue that the same restrictions apply in BP, RdP Spanish and Quebec French with respect to preposition optionality in certain non-standard relative clauses.

In order to account for this optionality, Kato (2010: 183) argues that, in fact, some prepositions, namely 'inherent' case marking prepositions (ICP), can be optional in the numeration. These include prepositions from PPs that are strictly subcategorized, but also prepositions in genitive complements and in indirect objects. In her preposition optionality proposal, Kato (2010) synthesizes the notion, shared by all the studies revised for this paper, that only prepositions with a close semantic relation to the verb can be deleted, or, in Kato's words "prepositions which encode inherent case" (p. 171).

\subsection{Preposition stranding}

As we can see in examples (14), reproduced here in (30), and (31), in addition to piedpiping and cortadora clauses, we may also find occasional examples of preposition stranding in BP.

(30) Você deve esquecer o assunto [[que $]_{i}$ eu te falei sobre $\left.[e c]_{i}\right]_{\text {. }}$

'You should forget the subject that I spoke to you about.'

(31) a. A moça com quem eu conversei na festa.

'The girl that I talked with at the party.'

b. A moça que eu conversei na festa.

'The girl that I talked (with) at the party.'

17 For European Portuguese, see note 10. 
As illustrated by Bouchard (1981), this is also the case in French, as we can see in examples (26), reproduced here in (32), and (33).

(32) a. Le fil que je coupe avec (PP instrument).

'The wire that I cut with.'

b. Le fil que je coupe le fromage.

'The wire that I cut the cheese.'

(33) La fille que je sors avec est correcte.

'The girl that I go out with is OK.'

This constitutes a notable difference with Spanish, where preposition stranding is ungrammatical even in varieties in which the cortadora structure has been attested. Any of the examples presented above would be ungrammatical in any variety of Spanish, as shown in (34).

a. *Deberías olvidar el asunto que te hablé sobre.

'You should forget the subject that I spoke to you about.'

b. *El cable que corto con.

'The wire that I cut with.'

c. *La chica que salgo con está bien.

'The girl that I go out with is OK.'

A noteworthy difference between the three languages, then, is that both French and Portuguese allow for preposition stranding in certain, whereas RdP Spanish does not. This difference, however, is not incompatible with the idea that Kato and Nunes's analysis can be extended to all three languages, with the notion of preposition optionality being at the core of the cortadora phenomenon. Specifically, cortadora relatives seem to be triggered by the semantic relation between prepositions and the corresponding licensing verbs - noninherent vs inherent case marking prepositions, as argued by Kato (2010) -, whereas the phenomenon of preposition stranding pertains to the way in which movement operates in each of the three languages discussed. Based on the RdP Spanish data, we must assume that the cortadora phenomenon is unrelated to preposition stranding or, at the very least, it is not conditioned by it.

\subsection{Towards a uniform account for relative clauses in Romance}

As we have seen throughout sections 2, 3 and 4, the three varieties display very similar characteristics and restrictions when it comes to both standard and non-standard relative clauses. Even though a full-fledged analysis of all types of relative clauses in Portuguese, French and Spanish would go beyond the scope of this study, we would like to suggest that the proposal by Kato and Nunes (2009) and Kato (2010) provide a sound theoretical basis to attempt this endeavour. Indeed, to account for their RdP data, Caviglia and Malcuori (2007) base their analysis on Kato (1993), which is also a main building block for Kato and Nunes's (2009) proposal, and Kato (2010) revisits Bouchard's (1981) data for French 
under the light of her proposal.

\section{Conclusions}

In this paper, we have set out to characterize the phenomenon of cortadora relative clauses found in RdP Spanish and compared it with 'chopping' relative clause phenomena also found in Portuguese and in French, two languages for which this topic construction has been more widely attested and accounted for in the literature. We have explored whether Kato and Nunes's (2009) proposal, which is able to provide a uniform raising account for both standard and non-standard relatives in Brazilian Portuguese, can successfully be extended to French (Kato, 2010) and RdP Spanish (Caviglia and Malcuori, 2007). We have also discussed Kato's (2010) argument on preposition optionality in these structures.

Following these authors, the absence of the preposition in cortadora relative clauses is not caused by deletion during the derivation, but to the fact that no preposition is actually selected in the numeration. Prepositions that can be optional include inherent case marking prepositions (ICP), but also prepositions in genitive complements and indirect objects. These prepositions can be deleted because they are recoverable thanks to their close semantic relation to their licensing verb. In terms of the syntactic structure of these relatives, the "orphan" DP complement in cortadora relative clauses must move to TopP in order to receive default nominative case. In contrast, in standard relative clauses, the PP complement is generated in an argument position, after which it moves to SpecCP, with the corresponding pied-piping and island effects. For their part, resumptives include the preposition is merged with the pronominal element in argument position, and a co-referent DP that merges in the left periphery.

In sum, despite the existence of certain differences, such as the presence of preposition stranding, albeit marginal, in Brazilian Portuguese and in French, but not in Spanish, we argue that the three languages display very similar characteristics, and that Kato and Nunes's (2009) proposal and Kato's (2010) argument on preposition optionality allow us to provide a uniform account for cortadora relative clauses in these three Romance languages.

\section{References}

Arim, Eva, Maria Celeste Ramilo \& Tiago Freitas. 2005. Mudança em curso e os média: o caso das relativas. In M. H. M. Mateus and F. Bacelar do Nascimento (eds.), A língua portuguesa em mudança, 67-80. Lisboa: Caminho.

Bagno, Marcos. 2001. Português ou brasileiro? Um convite à pesquisa. São Paulo: Parábola Ed.

Barros, A. Lucia de. 2000. O uso da relativa cortadora na fala pessoense. Unpublished Master's thesis, João Pessoa: Universidade Federal da Paraíba.

Bispo, Edvaldo B. 2009. Estratégias de relativização no portugués brasileiro e implicações para o ensino: o caso das cortadoras. Ph.D. thesis, Natal: Universidade Federal do 
Rio Grande do Norte.

Bosque, Ignacio \& Javier Gutiérrez-Rexach. 2009. Fundamentos de sintaxis formal. Madrid: Akal.

Bouchard, Denis. 1981. An alternative to Wh-movement French relative clauses. In W. W. Cressey and D. J. Napoli (Eds.), Linguistic Symposium on Romance Languages 9, 216-226. Washington: Georgetown University Press.

Burgos, Luiz Eduardo S. 2003. Estrategias de uso das relativas em uma comunidade de fala afro-brasileira. Unpublished Master's thesis, Salvador da Bahia: Universidade Federal da Bahia.

Castilho, Ataliba. 2010. Nova Gramática do Português Brasileiro. São Paulo: Contexto.

Caviglia, Serrana \& Marisa Malcuori. 2007. Las oraciones de relativo en la interfaz gramática-discurso. In V. Bertolotti et al. (eds.), Estudios de lingüística hispánica, 43-69. Cádiz: Universidad de Cádiz.

COLEM. 2014-2020. Corpus oral de la lengua española en Montreal, E. Pato (Dir.). Montreal: Université de Montréal. [www.esp-montreal.jimdo.com].

Contro Castaldo, Isabel Cristina. 2012. Las relativas cortadoras en la producción no nativa de estudiantes brasileños. Paper presented at VII Congresso Brasileiro de Hispanistas (3-6 setembro, 2012). Salvador da Bahia: Universidade Federal da Bahia.

COSER. 2005-2020. Corpus Oral y Sonoro del Español Rural, I. Fernández-Ordóñez (Dir.). Madrid: Universidad Autónoma de Madrid. [www.corpusrural.es].

Di Tullio, Ángela \& Marisa Malcuori. 2012. Gramática del español para maestros y profesores del Uruguay. Montevideo: Administración Nacional de Educación Pública.

Gomes Silva, Bianca Graziela S. \& Célia Regina dos Santos Lopes. 2007. O papel da freqüência na gramaticalização do que: análise das estratégias de relativização no português do Brasil. Veredas online. Revista de estudos lingüísticos 1: 80-100.

Kato, Mary. 1993. Recontando a história das relativas em uma perspectiva paramétrica. In I. Roberts and M. Kato (eds.), Português Brasileiro: uma viagem diacrônica. Homenagem a Fernando Tarallo. 223-261. Campinas: Editora da Unicamp.

Kato, Mary. 2010. Optional prepositions in Brazilian Portuguese. In K. Arregi et al. (eds.), Romance Linguistics 2008. Interactions in Romance, 171-184. Amsterdam/Philadelphia: John Benjamins. https://doi.org/10.1075/cilt.313.16kat

Kato, Mary \& Jairo Nunes, 2009. A uniform raising analysis for standard and non-standard relative clauses in Brazilian Portuguese. In J. Nunes (ed.), Minimalist Essays on Brazilian Portuguese Syntax, 93-120. Amsterdam/Philadelphia: John Benjamins. https://doi.org/10.1075/la.142.07kat

Kayne, Richard. 1994. The Antisymmetry of Syntax. Cambridge, Mass.: The MIT Press.

Kenedy, Eduardo. 2002. Aspectos estruturais da relativização em português: uma análise baseada no modelo raising. Unpublished Master's thesis, Rio de Janeiro: Universidade Federal do Rio de Janeiro.

Lope Blanch, Juan M. 1986. Despronominalización de los relativos. In J. M. Lope Blanch, Estudios de lingüística española, 119-136. Ciudad de México: Universidad Nacional Autónoma de México. 
Mateus, Maria Helena Mira \& Esperança Cardeira. 2007. Norma e Variação. Lisboa: Caminho.

Moura, Maria Denilda et al. 2010. Teoria da gramática: tendências e perspectivas. Revista Anpoll 29: 119-168.

https://doi.org/10.18309/anp.v1i29.176

Neves, Maria Helena de Moura. 2000. Gramática de usos do português. São Paulo: Universidade Estadual Paulista "Júlio de Mesquita Filho".

Real Academia Española/Asociación de Academias de la Lengua Española. 2009. Nueva gramática de la lengua española. Madrid: Espasa.

Remacle, Louis. 1960. Syntaxe du parler wallon de La Gleize. Paris: Société d'Édition 'Les Belles Lettres'.

Tarallo, Fernando. 1983. Relativization Strategies in Brazilian Portuguese. Ph.D. thesis, University of Pennsylvania.

Trujillo, Ramón. 1990. Sobre la supuesta despronominalización del relativo. Estudios de Lingüística de la Universidad de Alicante 6: 23-45. https://doi.org/10.14198/elua1990.6.02

Valer, Salete. 2008. As sentenças relativas com núcleo nominal nos dados de fala (projeto VARSUL) de Florianópolis. Unpublished Master's thesis, Florianópolis: Universidade Federal de Santa Catarina.

Varejão, Filomena. 2006. Variação em estruturas de concordância verbal e em estratégias de relativização no português europeu popular. Rio de Janeiro: Universidade Federal do Rio de Janeiro.

Vinet, Marie-Thérèse. 1979. Dialect Variation and a Restrictive Theory of Grammar: A Study of Intransitive Prepositions in a Variety of French. Montreal Working Papers in Linguistics 13: 107-125. 